\begin{tabular}{|c|} 
Jurnal Keolahragaan \\
Volume 4 - Nomor 2, September 2016, (196-206) \\
Tersedia online: http://journal.uny.ac.id/index.php/jolahraga
\end{tabular}

\title{
PENGARUH LATIHAN IMAGERY DAN KOORDINASI TERHADAP KETERAMPILAN FOREHAND DRIVE PETENIS PEMULA
}

\author{
Risti Nurfadhila \\ Universitas PGRI Semarang. Jalan Sidodadi Timur Nomor 24 - Dr. Cipto Semarang, Indonesia \\ Korespondensi Penulis. Email: ristinurfadhila@gmail.com, Telp: (+6224) 8316377
}

Received: 16 September 2016; Revised: 27 October 2016; Accepted: 31 October 2016

\begin{abstract}
Abstrak
Penelitian ini bertujuan untuk mengetahui: (1) perbedaan pengaruh antara latihan imagery dengan menggunakan script dan video terhadap keterampilan forehand drive petenis pemula, (2) perbedaan keterampilan forehand drive antara petenis pemula yang memiliki koordinasi tinggi dan koordinasi rendah, (3) interaksi antara latihan imagery dan koordinasi terhadap keterampilan forehand drive petenis pemula. Metode penelitian adalah eksperimen dengan rancangan faktorial $2 \times 2$. Sampel penelitian adalah 32 orang petenis pemula mahasiswa PJKR FIK UNY yang mengambil mata kuliah olahraga pilihan tenis yang diambil dengan teknik Purposive Random Sampling. Seluruh data penelitian diperoleh melalui tes dan pengukuran terhadap koordinasi dengan menggunakan tes koordinasi mata-tangan serta keterampilan forehand drive dengan Hewitt Tennis Test. Teknik analisis data yang digunakan adalah Analisis Varian (ANAVA) dua jalur yang dilanjutkan dengan uji pairwise comparisons pada taraf signifikan $\alpha=0,05$. Hasil penelitian menunjukkan bahwa: (1) Ada perbedaan pengaruh yang signifikan antara latihan imagery dengan menggunakan script dan video terhadap keterampilan forehand drive. (2) Ada perbedaan keterampilan forehand drive antara petenis pemula yang memiliki koordinasi tinggi dan koordinasi rendah. (3) Ada interaksi antara latihan imagery dan koordinasi terhadap keterampilan forehand drive petenis pemula.
\end{abstract}

Kata Kunci: Latihan imagery, koordinasi, tenis, keterampilan forehand drive.

\section{THE EFFECT OF IMAGERY EXERCISE AND COORDINATION ON BEGINNER TENNIS PLAYER'S FOREHAND DRIVE SKILL}

\begin{abstract}
This study aims to determine: (1) the difference of effect between the imagery exercise using script and video on the forehand drive skill of beginner tennis players, (2) the difference of forehand drive skill of beginner tennis players with high and low coordination, and (3) the interaction between the imagery exercise and the coordination on the forehand drive skill of beginner tennis players. The method of research was experimental with $2 \times 2$ factorial designs. Sample of research was 32 students of Physical Education Health and Recreation Study Program of The Faculty Sport ScienceUniversitas Negeri Yopgyakarta who take tennis lesson which taking with purposive random sampling technique. Data were obtained by a test and measurement on the coordination using eye-hand coordination test. Besides, forehand drive skills measurement was obtained by using Hewitt Tennis Test. The data analysis technique used was the two lines variant analysis (ANAVA) followed by pairwise comparisons test at a significance level of $\alpha=0.05$. The results of this research indicate that: (1) there is a significant difference between imagery exercise using script and video on forehand drive skill. (2) there is a difference of forehand drive skills between beginner tennis players with high and low coordination. (3) there is an interaction between imagery exercise and coordination on forehand drive sklill of beginner tennis player.
\end{abstract}

Keywords: imagery exercise, coordination, tennis, forehand drive skill.

How to Cite: Nurfadhila, R. (2016). Pengaruh latihan imagery dan koordinasi terhadap keterampilan forehand drive petenis pemula.Jurnal Keolahragaan, 4(2), 196 - 206. doi:http://dx.doi.org/10.21831/jk.v4i2.10898

Permalink/DOI: http://dx.doi.org/10.21831/jk.v4i2.10898 


\section{PENDAHULUAN}

Tenis merupakan salah satu cabang olahraga yang menggunakan bola kecil dan setiap pemainnya memakai raket sebagai alat pemukul bola. Permainan ini dilakukan di atas lapangan yang berbentuk empat persegi panjang yang terbuat dari semen, tanah dengan campuran pasir-pasir halus (gravel), bahkan dimainkan juga di atas rumput. Lapangan tersebut dibagi dua sama besar oleh sebuah net. Dalam permainan tenis kebanyakan bola dipukul setelah memantul satu kali dan tidak boleh memantul di tanah lebih dari satu kali. Selain itu, diperbolehkan juga memukul bola saat melayang di udara sebelum memantul tanah.

Permainan tenis dapat dimainkan sebagai permainan tunggal antara dua pemain maupun permainan ganda atau tim antara dua pasangan pemain. Sistem pertandingan yang digunakan dalam permainan tenis lapangan di antaranya ada the best of seventeen, the best of five dan the best of three sets. Dalam setiap sistem pertandingan tersebut terdiri atas serangkaian poin yang membentuk suatu game; sejumlah game tersebut akan membentuk suatu set, dan akhirnya jumlah set akan membentuk suatu sistem pertandingan.

Prinsip dasar dalam bermain tenis adalah memukul bola melewati atas net dan masuk ke dalam lapangan permainan lawan. Tugas petenis adalah mengirim dan mengembalikan bola melewati net ke lapangan permaian lawan. Saat memukul bola harus diusahakan agar menyulitkan lawan dalam pengembaliannya. Untuk dapat menempatkan bola pada posisi yang diinginkan, bola dapat dikendalikan dengan mengontrol permukaan raket saat terjadinya impact dengan bola.

Dalam permainan tenis yang utama adalah berusaha untuk menjangkau seluruh lapangan serta keajegannya dalam memukul bola agar masuk ke dalam lapangan permainan lawan. Petenis dalam menjangkau seluruh lapangan permainan dapat dengan cara berlari atau berjalan ke samping, ke depan, ke belakang, melompat, meluncur (sliding), memutar dengan cepat agar dapat memukul bola.

Tenis lapangan merupakan salah satu cabang olahraga yang berkembang di Indonesia. Salah satu indikasinya adalah tenis lapangan dijadikan mata kuliah pada universitas yang memiliki fakultas atau jurusan keolahragaan sebagai upaya pemasalan cabang olahraga tenis lapangan. Target dari mata kuliah olahraga tenis lapangan tersebut adalah mahasiswa dapat mencapai keterampilan tenis yang optimal. Namun pada pelaksanaannya pola latihan yang diterapkan kepada mahasiswa kurang diimbangi dengan pola latihan yang baik yang mana memperhatikan segala aspek yang ada. Fakta yang ditemukan berdasarkan observasi yang dilakukan pada empat universitas yang memiliki fakultas atau jurusan olahraga yang melaksanakan mata kuliah tenis lapangan mendapati bahwa latihan yang diterapkan dalam proses latihan atau pembelajaran tenis lapangan kurang optimal karena hanya menerapkan latihan fisik tanpa menerapkan latihan psikis dan setiap individu diberikan bentuk latihan yang sama tanpa memperhatikan prinsip individual.

Kaitannya dengan penampilan yang optimal dalam bermain tenis tentunya banyak faktor yang memengaruhi pencapaian tersebut. Salah satunya adalah keberhasilan proses latihan yang dipengaruhi oleh kualitas latihan yang diterapkan semenjak petenis pemula. Sejak pemula, petenis harus dilatih secara baik dan benar. Menurut Sukadiyanto (2010, p.4) kualitas latihan ditentukan terutama oleh keadaan dan kemampuan pelatih serta olahragawan. Keduanya harus memiliki kemampuan, kemauan, dan komitmen yang tinggi untuk meraih hasil yang terbaik.

Dalam permainan tenis lapangan, pengertian petenis pemula dibedakan menjadi dua, yaitu: (1) petenis pemula berdasarkan tingkat keterampilan yang dimiliki oleh tiap individu, (2) petenis pemula berdasarkan pada usia individu. Penelitian ini berkaitan dengan petenis pemula berdasarkan tingkat keterampilan individu, jadi tidak terbatas pada umur.

Pencapaian hasil latihan atau pembelajaran yang optimal dalam cabang olahraga tenis lapangan dapat dicapai melalui peranan yang sangat penting dari seorang pelatih. Oleh karena itu, pelatih harus mampu menyusun program, memilih, dan menerapkan metode latihan sesuai dengan tujuan latihan itu sendiri. Usaha pemasalan, pembinaan, dan pengembangan untuk mencapai penampilan yang optimal tersebut perlu diadakan pendekatan ilmiah, adanya sarana yang menunjang dan metode latihan yang tepat. Untuk pencapaian yang optimal dalam permainan tenis lapangan faktor yang mendasar yang perlu dikuasai oleh petenis adalah pukulan dasar atau teknik dasar permainan tenis.

Dalam semua permainan, bahkan semua jenis olahraga terutama pada jenis olahraga yang menggunakan alat, maka keterampilan 
dasar untuk dapat bermain olahraga tersebut harus diketahui, dimengerti dan dipelajari lebih dahulu. Artinya sebelum melakukan atau belajar olahraga tersebut, maka keterampilan dasarnya (dalam hal ini keterampilan dasar memukul bola) harus dipelajari terlebih dahulu. Dengan mempelajari keterampilan dasar memukul bola yang benar dan tepat sedini mungkin, maka perkembangan penguasaan pukulan selanjutnya akan mencapai hasil yang optimal.

Penguasan pukulan dasar yang baik dan benar merupakan salah satu landasan penting untuk meningkatan kecakapan dalam bermain tenis. Bagi petenis, penguasaan teknik dasar pukulan mutlak diperlukan dalam bermain tenis. Untuk itu pukulan dasar perlu dilatihkan dengan baik dan benar sejak awal latihan pada petenis pemula. Penguasaan teknik dasar dapat dicapai dengan latihan yang benar, tepat, dan teratur.

Sukadiyanto (2010, p.29) menyatakan terdapat empat pukulan dasar dalam tenis, yaitu: (a) groundstroke terdiri atas (forehand dan backhand), (b) volley terdiri atas (forehand dan backhand), (c) servis, dan (d) lob serta smash. Groundstrokes merupakan teknik pukulan bawah yang dilakukan setelah bola memantul dari lapangan. Teknik groundstrokes terdiri atas dua jenis pukulan, yaitu: forehand drive dan backhand drive. Jenis pukulan tersebut merupakan pukulan dasar yang dominan dilakukan selama permainan tenis berlangsung. Forehand drive merupakan pukulan yang sangat penting dan merupakan suatu modal bagi petenis untuk dapat bermain tenis sehingga jenis pukulan ini harus benar-benar dilatih agar memiliki modal yang kuat. Hal ini diperkuat dengan pendapat Brown (2007, p.31) yang menyatakan sedikitnya setengah dari seluruh pukulan tenis adalah forehand, maka pukulan forehand sangat penting. Forehand drive sering dijadikan senjata karena hasil pukulannya lebih keras dibanding pukulan lainnya.

Brown (2010, p.31) menjelaskan forehand drive adalah pukulan yang termasuk groundstroke, yaitu pukulan setelah bola memantul di lapangan. Menurut Cholid (2010, p.6) forehand drive adalah pukulan yang dilakukan dengan cara mengayunkan raket ke sebelah kanan belakang badan menuju ke depan badan dan bagian depan raket atau telapak tangan berhadapan dengan bola. Forehand drive adalah "Pukulan yang termasuk golongan groundstroke, yaitu pukulan yang dilakukan terhadap bola yang sudah menyentuh tanah (lapangan) dengan pukulan datar di atas net."

Forehand drive adalah pukulan yang paling penting bagi seorang pemula. Berdasarkan pendapat beberapa ahli tersebut dapat disimpulkan bahwa forehand drive adalah suatu pukulan dalam permainan tenis lapangan yang dilakukan dalam suatu swing atau ayunan ke samping kanan secara penuh, kemudian dengan raket diayunkan ke samping badan lalu diayunkan ke depan untuk memukul bola di atas net setelah memantul sekali di lapangan.Terdapat beberapa tahapan dalam melakukan gerakan forehand drive, yaitu ready position, mengayunkan raket ke belakang (back swing), mengayunkan raket ke depan (foward swing) dan melakukan gerak lanjutan (follow through). Oleh karena itu, untuk dapat menghasilkan pukulan forehand drive yang bagus diperlukan koordinasi yang baik.

Menurut Sukadiyanto (2005, p.139) koordinasi merupakan hasil perpaduan kinerja dari kualiatas otot, tulang, dan persendian dalam menghasilkan satu gerak yang efektif dan efisien. Syafruddin (2011, pp.118-119) berpendapat bahwa koordinasi merupakan salah satu elemen kondisi fisik yang relatif sulit didefinisikan secara tepat karena fungsinya terkait dengan elemen-elemen kondisi fisik yang lain dan ditentukan oleh kemampuan siswa.

Koordinasi dianggap baik apabila mampu menampilkan/melakukan gerakan pada tingkat kesukaran yang tinggi dengan cepat, tepat dan efisiensi gerak yang tinggi Halim $(2009$, p.121) mengutarakan dasar fisiologis dari komponen koordinasi ini adalah hasil dari proses syaraf pada sistem syaraf pusat. Salah satu fungsi dari sistem syaraf pusat adalah memilih dan memutuskan sebuah jawaban dengan cepat dan tepat untuk merespon rangsangan melalui syaraf eferen menuju ke efector tertentu. Menurut Bompa (Halim, 2009, p.122) terdapat empat faktor yang berpengaruh terhadap koordinasi, yaitu: (1) inteligensia, (2) Kepekaan organ sensoris, (3) pengalaman motorik, dan (4) tingkat pengembangan kemampuan biomotorik.

Menurut Sukadiyanto (2010, p.139) forehand drive merupakan pukulan dengan gerakan yang kompleks karena melibatkan sinkronisasi dari beberapa gerakan untuk menghasilkan serangkaian gerakan yang efektif dan efisien, sehingga diperlukan komponen biomotor yang baik guna mendukung keterampilan forehand drive. Koordinasi yang diperlukan dalam melakukan forehand drive pada olahraga tenis 
adalah koordinasi mata dan gerakan lengan pada saat memukul bola. Pada saat bola tenis datang ke arah petenis mata berperan sebagai penerima stimulus dan raket berfungsi sebagai perpanjangan lengan yang merespon dengan cara memukul bola tenis yang datang. Dengan demikian, koordinasi mata tangan sangat menentukan keberhasilan petenis dalam melakukan forehand drive untuk menghasilkan pukulan yang efektif dan efisien. Sependapat dengan Sukadiyanto (2003, p.115) bahwa tanpa memiliki kemampuan koordinasi gerak yang baik, individu akan kesulitan dalam belajar keterampilan teknik-teknik dasar pukulan tenis.

Namun, kemampuan koordinasi setiap orang tentunya berbeda-beda ada yang memiliki kemampuan koordinasi tinggi ada juga yang memiliki kemampuan koordinasi rendah. Oleh karena itu, merujuk pada prinsip latihan individual bahwa seseorang harus dilatih sesuai dengan kemampuan masing-masing. Menurut Irianto $(2009$, p.8) setiap orang memiliki potensi yang berbeda-beda dan berkarakter unik, setiap latihan menimbulkan respon yang berbeda pula. Oleh karena itu dalam proses latihan metode latihan yang diterapkan kepada anak latih harus sesuai dengan karakteristik fisiologis dan psikologis anak latih, sehingga tujuan latihan dapat tercapai secara optimal.

Metode latihan yang diterapkan merupakan faktor yang berpengaruh terhadap kemampuan petenis dalam melakukan forehand drive. Keberhasilan pelatih atau pengajar dalam meningkatkan kemampuan keterampilan gerak anak latih dipengaruhi oleh metode latihan yang diterapkan. Ketepatan dalam menerapkan metode latihan yang diterapkan dalam latihan akan memengaruhi pencapaian anak latih selama proses latihan.

Namun, pada umumnya metode latihan yang dilakukan sekarang ini masih sering menghasilkan latihan yang kurang efektif. Berdasarkan pengamatan kecenderungan pelatih atau pengajar hanya menitikberatkan pada latihan fisik. Banyak pelatih atau pengajar yang tidak tahu tentang pelaksanaan latihan selain latihan yang nampak nyata dalam peragaan fisik. Salah satu metode terbaik untuk meningkatkan keterampilan gerak adalah latihan yang secara langsung mempelajari kegiatan/aktivitas keterampilan gerak tersebut dengan praktek secara berulang-ulang. Dengan praktik berulang-ulang seseorang akan memperoleh pola otomatis dari teknik keterampilan gerak yang dipelajarinya.
Latihan imagery dengan cara script dan video imagery sebagai bentuk latihan psikis umumnya belum banyak dilaksanakan oleh pelatih atau pengajar dalam pelaksanaan latihan untuk anak latih. Hal ini disebabkan masih banyak pelatih atau pengajar yang asing mengenai konsep teknik latihan imagery.

Weinberg \& Gould (2007, p.296) menyatakan imagery adalah bentuk dari simulasi. Purnama (2013, p.40) menyatakan bahwa latihan imagery adalah suatu latihan dalam alam fikiran atlet, yang mana atlet membuat gerakangerakan yang benar-benar melalui imajinasi dan setelah dimatangkan kemudian dilaksanakan. Tekanan pokok dalam latihan imagery adalah semua atlet harus sudah memperoleh pengertian mengenai keterampilan dan bagaimana cara serta pola gerak yang akan dilakukan dalam keterampilan nyata. Pertama, atlet diberi gambaran mengenai teknik yang akan dilatihkan (apabila tujuan latihan adalah tentang penguasaan teknik).

Menurut Orlick (Gunarso, 2008, p.103) imagery merujuk pada proses merasakan yang sangat intens, seolah-olah perasaan tersebut merupakan keadaan yang sebenarnya. Imagery adalah serangkaian aktivitas membayangkan atau memunculkan kembali dalam pikiran suatu objek, peristiwa atau pengalaman gerak yang benar dan telah disimpan dalam ingatan. Berbagai hasil penelitian menunjukkan bahwa Imagery dapat memfasilitasi peningkatan performa olahraga.

Purnama (2013, p.43) menyatakan latihan imagery memengaruhi belajar dan penampilan karena memungkinkan individu mengulang rangkaian gerak dengan membuat komponen-komponen simbolik dalam otak yang dibutuhkan untuk memfasilitasi performa keterampilan yang akan dilakukan dan dapat menguatkan hubungan stimulus respon.

Penetapan tujuan dan imagery merupakan bagian integral dari keseluruhan keterampilan psikologis. Membayangkan tujuan merupakan suatu cara yang efektif untuk mengarahkan atlet terhadap pencapaian tujuan dan imajeri mental dapat berhasil dengan efektif ketika atlet menetapkan tujuan yang spesifik dan realistik selama latihan imagery. Kian jelas dan detail objek atau gerakan yang dibayangkan, maka kian besar kemungkinan petenis akan mampu melihat peluang-peluang yang dapat mewujudkan tujuan. Selain itu, dengan membuat gambaran atau bayangan yang sangat spesifik petenis dapat menentukan aspek-aspek 
kritis atau komponen-komponen kunci yang harus menjadi fokus perhatian selama proses latihan sehingga tujuan akan lebih mudah dan cepat tercapai. Karena itu, tujuan dapat dibayangkan dan proses membayangkan harus terarah pada tujuan. Inilah cara terbaik untuk melakukan imagery. Rushall (2008, p.57) latihan imajeri (mental imagery) merupakan suatu bentuk latihan mental yang berupa pembayangan diri dan gerakan di dalam pikiran.

Dapat disimpulkan bahwa imagery merupakan bentuk latihan mental yang dilakukan dengan cara membayangkan atau memunculkan kembali dalam pikiran suatu objek, serangkaian aktivitas, peristiwa atau pengalaman gerak yang benar dan telah disimpan dalam ingatan.

Tujuan utama imagery digunakan dalam olahraga menurut Murphy (2005, p.138), di antaranya yaitu: (1) mempelajari keterampilan baru, (2) melatih kembali keterampilan sepanjang waktu, (3) ritual sebelum tampil, (4) mengembangkan strategi dan rencana, (5) mengurangi kecemasan pertandingan, (6) meningkatkan psikologis, (7) mengatur ketegangan, (8) meningkatkan kepercayaan, (9) meningkatkan motivasi, (10) meningkatkan konsentrasi, (11) rehabilitasi dari cedera, dan (12) membangun kerja sama tim. Hal ini juga diperkuat oleh Tenenbaum dan Eklund (2007, p.296) yang menyatakan manfaat imagery di antaranya, yaitu untuk pengembangan dan perbaikan keterampilan mental, pengenalan tempat bertanding kepada atlet, serta pemanasan secara mental.

Imagery tidak terbatas pada visualisasi saja, tetapi juga merujuk kepada indera keseimbangan (kinesthetic), indera pendengaran (auditory), indera perabaan (tactile), indera penciuman (olfactory) yang semuanya adalah penting secara potensial. Penggunaan lebih dari satu indera akan membantu untuk menciptakan gambaran yang lebih hidup. Menurut Moran \& MacIntyre (Weinberg \& Gould, 2007, p.297) penggunaan indera kinestetik penting sekali terutama bagi atlet, karena indera kinestetik mencakup bagaimana cara merasakan tubuh yang bergerak dalam posisi yang berbeda dan hal ini merupakan penggunaan yang utama untuk meningkatkan penampilan/performa.

Latihan imagery dapat dilakukan kapan saja. Menurut Weinberg \& Gould (2007, p.316) imagery dapat dilakukan sebelum dan setelah latihan, sebelum dan sesudah kompetisi, selama off-sesason, selama pertandingan (pada waktu breaks), selama waktu pribadi seperti di rumah atau di tempat lainnya. Atlet juga menggunakan imagery ketika atlet tersebut cedera, walaupun penelitian menyatakan bahwa penggunaan imagery lebih banyak digunakan selama kompetisi dan latihan daripada selama rehabilitasi cedera. Kapan imagery digunakan untuk tujuan rehabilitasi, fokusnya adalah untuk memelihara dalam memotivasi untuk sembuh dan melatih kembali latihan rehabilitasi. Menurut Burke (Dosil, 2006, p.128) imagery pada waktu cedera dapat digunakan untuk dua tujuan utama, yaitu: (1) digunakan untuk melatih keterampilan dan strategi secara mental ketika atlet tidak mengikuti latihan fisik, jadi atlet masih bisa bersama tim saat latihan; dan (2) membantu proses rehabilitasi, dengan memberikan atlet perasaan pribadi yang lebih kuat untuk mengontrol semua proses pemulihan.

Menurut Weinberg \& Gould (2007, p.300) terdapat empat tipe imagery yaitu visual, kinestetik, auditori dan olfactory. Imagery visual dan kinestetik merupakan hal yang penting dalam imagery. Terdapat beberapa metode dalam melakukan imagery di antaranya adalah dengan memasang foto, gambar atau poster petenis idola; melihat video dan dengan panduan naskah.

Pelaksanaan latihan ini di lapangan bukan berarti bahwa latihan ini sepenuhnya dapat menggantikan latihan yang nyata tampak dalam peragaan fisik, tetapi kedua-duanya harus diberikan dalam satu kesatuan atau harus saling mengisi untuk mengoptimalkan keterampilan gerak dasar anak latih selama proses latihan.

Menurut Shearer et.al (2009, p.3) script imagery merupakan pendekatan tradisional latihan imagery dengan naskah tertulis sebagai panduan latihan. Williams (2013, p.110) berpendapat bahwa script imagery adalah latihan imagery yang menggunakan panduan pengalaman imagery berupa script atau naskah. Dapat disimpulkan bahwa script imagery adalah bentuk latihan imagery yang menggunakan naskah sebagai panduan pelaksanaanya.

Terdapat beberapa hal yang perlu diperhatikan dalam menyusun script imagery. Menurut Williams (2013, p.110) terdapat empat hal yang perlu diperhatikan dalam menyususn script untuk latihan imagery di antaranya: (1) siapa yang akan menggunakan script, (2) kapan dan di mana script digunakan, (3) mengapa script digunakan, dan (4) apa yang akan dibayangkan. Menurut Williams (2013, p.114) script imagery memiliki fungsi spesifik kognitif (meningkatkan keterampilan), fungsi umum kognitif (meningkatkan strategi dan gambe 


\section{Jurnal Keolahragaan 4 (2), September 2016 - 201}

Risti Nurfadhila

plans), fungsi motivasi spesifik, dan fungsi umum motivasi.

Dari teknis pelaksanaan latihan script imagery yang sudah dijelaskan tersebut, dapat dilihat bahwa dalam pelaksanaannya membutuhkan daya imajinasi, persepsi dan koordinasi yang tinggi. Keunggulan dari latihan script imagery adalah tepat diterapkan bagi anak latih yang memiliki kemampuan persepsi dan koordinasi yang baik; dan dapat mengembangkan daya imajinasi serta daya pikir anak latih. Setiap bentuk atau metode latihan pasti memiliki kelemahan dalam penerapannya saat latihan. Menurut Shearer et.al. (2009, p.3) kelemahan dari latihan script imagery adalah mencegah akses temporal representasi dari keterampilan yang diinginkan. Bagi pemula akan mendapatkan bayangan yang kurang jelas mengenai teknik gerakan yang akan dilakukan apabila hanya dijelaskan mengenai teknik dalam melakukan suatu gerakan karena akan sangat sulit memvisualisasikan suatu gerakan yang belum pernah dilihat.

Selain dengan latihan script imagery, latihan imagery dapat dilakukan dengan bantuan video seseorang yang sedang melakukan suatu gerakan. Banyak atlet yang memperoleh gambaran yang bagus dan jelas dengan cara melihat suatu video. Menurut Shearer (2009, p.3) video imagery merupakan suatu bentuk latihan imagery dengan menggunakan video sebagai alat bantu. Huda (2013, p.289) berpendapat bahwa video imagery merupakan bentuk latihan yang melibatkan banyak indera (multisensory). Berdasarkan hasil penelitian video imagery membantu mengembangkan kemampuan imagery, memberikan gambaran yang detail/rinci, multisensory, dan prosisi stimulus (Shearer, 2009, p.9).

Latihan video imagery dapat dilakukan hampir setiap saat dengan bantuan melihat video. Video imagery dapat dilakukan sebelum maupun sesudah latihan, dan dapat dilakukan di waktu luang. Pada pelaksanaan latihan video imagery, rekaman yang dilihat dapat berupa rekaman diri sendiri pada saat bermain atau melakukan suatu gerakan dan rekaman orang lain yang sedang melakukan suatu gerakan. Bagi profesional melihat video rekaman diri sendiri pada saat bermain atau melakukan suatu gerakan digunakan untuk mengoreksi teknik yang telah dilakukan pada saat bermain. Bagi pemula disarankan melihat rekaman dari orang lain, di mana orang lain tersebut adalah seorang profesional dikarenakan gerakan yang dilaku- kan seorang profesional memiliki tingkat kesalahan gerak yang minim atau dapat dikatakan mendekati sempurna, sehingga apa yang pemula tersebut lihat merupakan gerakan teknik yang benar.

Tujuan melihat video adalah untuk membantu mengembangkan kemampuan imagery, memberikan gambaran yang detail/rinci, multisensory, dan proposisi stimulus (Shearer, 2009, p.9). Video yang memvisualisasikan gerakan seseorang dalam melakukan suatu gerakan forehand drive dengan teknik yang baik dan benar akan sangat membantu seorang petenis dalam mengembangkan keterampilan forehand drive yang dimiliki.

Menurut Smith \& Holmes (Shearer, 2009, p.3) video imagery lebih efektif daripada script imagery. Video imagery dapat dijadikan suatu solusi yang diberikan untuk meningkatkan efektivitas intervensi imagery dengan memutar kembali video rekaman saat atlet sedang bermain.

Keunggulan metode ini adalah bagi pemula sangat besar manfaatnya, karena dapat memberikan stimulus yang dapat merangsang munculnya imajinasi dalam diri atlet untuk mendapatkan gambaran yang jelas. Selain itu video imagery tepat diterapkan pada anak latih yang memiliki kemampuan persepsi dan koordinasi yang kurang baik. Dikaitkan dengan metode pengajaran dan pembelajaran, menurut Huda (2013, p.289) gaya belajar yang melibatkan visual, auditori, dan kinestetik adalah gaya belajar multi-sensorik yang lebih baik daripada gaya belajar yang hanya sekedar membaca buku karena melibatkan lebih banyak indera sehingga akan mengahasilkan hasil belajar yang optimal. Video imagery dapat mengoptimalkan panca indera.

Selain memiliki keunggulan latihan video imagery juga memiliki kelemahan. Kelemahan dari metode ini adalah imagery dengan metode melihat video kurang efisien waktunya karena harus mempersiapkan berbagai peralatan.

Berdasarkan uraian tersebut dibutuhkan suatu penelitian mengenai metode latihan mental yang efektif untuk meningkatkan kemampuan keterampilan forehand drive petenis khususnya petenis pemula berdasarkan karakteristik tingkat keterampilan individu. Untuk itu, perlu diadakan penelitian yang berkaitan dengan penerapan metode latihan mental dan keterampilan petenis pemula.

Dalam penelitian ini yang diteliti perbedaan pengaruh antara dua metode latihan 
imagery, yaitu script imagery dan video imagery yang diterapkan pada mahasiswa yang memiliki kemampuan koordinasi tinggi dan mahasiswa yang memiliki variabel independen atributif terhadap keterampilan forehand drive sebagai variabel dependen. Masalah penelitian, yaitu: (1) adakah perbedaan pengaruh antara latihan imagery dengan menggunakan latihan script dan video imagery terhadap keterampilan forehand drive petenis pemula?, (2) adakah perbedaan keterampilan forehand drive antara petenis pemula yang memiliki kemampuan koordinasi tinggi dengan petenis pemula yang memiliki koordinasi rendah?, dan (3) adakah interaksi antara latihan imagery dan koordinasi terhadap keterampilan forehand drive petenis pemula?. Tujuan penelitian untuk (1) mengetahui perbedaan pengaruh antara latihan imagery dengan menggunakan latihan script dan video imagery terhadap keterampilan forehand drive petenis pemula?, (2) mengetahui perbedaan keterampilan forehand drive antara petenis pemula yang memiliki kemampuan koordinasi tinggi dengan petenis pemula yang memiliki koordinasi rendah?, dan (3) mengetahui interaksi antara latihan imagery dan koordinasi terhadap keterampilan forehand drive petenis pemula?

\section{METODE}

Penelitian ini menggunakan metode eksperimen dengan desain penelitian faktorial $2 \times 2$. Penelitian ini bertempat di Lapangan Tenis Fakultas Ilmu Keolahragaan Universitas Negeri Yogyakarta. Waktu pelaksanaan latihan pada masing-masing kelompok dalam waktu yang bersamaan yaitu dimulai pada tanggal $11 \mathrm{Mei}$ 2014-15 Juni 2014 sebanyak 16 kali pertemuan.

Populasi dalam penelitian ini adalah petenis pemula yaitu mahasiswa Pendidikan Jasmani, Kesehatan dan Rekreasi Fakultas Ilmu Keolahragaan Universitas Negeri Yogyakarta yang mengikuti mata kuliah olahraga pilihan tenis lapangan berjumlah 60 orang. Sampel penelitian diambil setelah dilakukan tes koordinasi mata tangan pada populasi penelitian. Dari hasil tes koordinasi mata tangan dirangking kemudian diambil $27 \%$ kelas atas dan $27 \%$ kelas bawah populasi penelitian sehingga didapatkan sampel penelitian berjumlah 32 orang. Sampel yang berjumlah 32 orang tersebut diba- gi ke dalam empat kelompok, yaitu: (1) kelompok yang diberikan metode script imagery untuk kelompok dengan koordinasi tinggi sebanyak 8 orang, (2) kelompok yang diberikan metode video imagery untuk kelompok dengan koordinasi tinggi sebanyak 8 orang, (3) kelompok yang diberikan metode script imagery untuk kelompok dengan koordinasi rendah sebanyak 8 orang, (4) kelompok yang diberikan metode video imagery untuk kelompok dengan koordinasi rendah sebanyak 8 orang.

Dalam penelitian ini variabel terdiri atas dua variabel, yaitu: (1) variabel bebas manipulatif, yang terdiri atas (a) script imagery, (b) video imagery; dan (2) variabel bebas atributif terdiri atas (a) koordinasi tinggi, (b) koordinasi rendah. Variabel terikatnya adalah keterampilan forehand drive.

Sesuai dengan variabel yang diteliti terdapat dua macam data yang harus dikumpulkan, yaitu (1) data koordinasi, dan (2) data keterampilan forehand drive. Teknik pengumpulan data koordinasi dan keterampilan forehand drive menggunakan tes dan pengukuran. Instrumen tes koordinasi menggunakan tes koordinasi mata-tangan dengan validitas sebesar 0,67 dan reliabilitas sebesar 0,867. Instrumen keterampilan forehand drive menggunakan Hewitt Tennis Test dari J.E. Hewitt dengan validitas sebesar 0,67 dan reliabilitas sebesar 0,75.

Teknik analisis data yang digunakan anava dua jalur (two ways ANOVA) pada taraf signifikansi $\alpha=0,05$. Sebelum teknik analisis varians digunakan, terlebih dahulu dilakukan uji prasyarat analisis yang meliputi uji normalitas dan uji homogenitas. Uji normalitas menggunakan uji Kolmogorof-Smirnov. Uji homogenitas varians menggunakan uji Levene's test. Setelah uji prasyarat dan uji hipotesis dilakukan, karena terdapat interaksi maka dilanjutkan dengan uji pairwise comparisons.

\section{HASIL DAN PEMBAHASAN}

Hasil yang diperoleh berupa data yang merupakan gambaran umum tentang masingmasing variabel yang terkait dalam penelitian. Data hasil penelitian berupa data pretest forehand drive dan posttest forehand drive. Nilai beda pretest dan posttest keterampilan forehand drive merupakan pengaruh proses latihan (treatment) yang telah diberikan. 
Jurnal Keolahragaan 4 (2), September 2016 - 203

Risti Nurfadhila

Tabel 1. Deskripsi Data Pretest dan Posttest Keterampilan Forehand Drive

\begin{tabular}{cccccc}
\hline Tingkat Koordinasi & Metode Latihan & Statistik & Hasil Tes Awal & Hasil Tes Akhir & Peningkatan \\
\hline \multirow{4}{*}{ Tinggi } & Script & Jumlah & 110 & 187.00 & 77 \\
& A1B1 & Rerata & 13.75 & 23.38 & 9,63 \\
& & SD & 6.52 & 4,87 & 7,23 \\
& Video & Jumlah & 93 & 159 & 66 \\
& A2B1 & Rerata & 11,63 & 19,88 & 8,25 \\
Rendah & SD & 4,81 & 2,47 & 4,46 \\
& Script & Jumlah & 82 & 102 & 20 \\
& A1B2 & Rerata & 10,25 & 12,75 & 3,02 \\
& Video & SD & 5,80 & 4,33 & 76 \\
& A2B2 & Rerata & 112 & 188 & 9,5 \\
\end{tabular}

Pada Tabel 1 dapat dilihat perbandingan peningkatan rerata setiap kelompok perlakuan yaitu: (1) pada kelompok script imagery pada kelompok sampel yang memiliki koordinasi tinggi (A1B1) hasilnya 9,63; (2) pada kelompok video imagery pada sampel yang memiliki koordinasi tinggi (A2B1) hasilnya 8,25; (3) pada kelompok script imagery pada kelompok sampel yang memiliki koordiansi rendah (A1B2) hasilnya 2,5; dan (4) pada kelompok video imagery pada kelompok sampel yang memiliki koordinasi rendah (A2B2) hasilnya 9,5 .

\section{Uji Normalitas Data}

Berdasarkan hasil analisis uji normalitas pada test keterampilan forehand drive dengan menggunakan uji $Z$ Kolmogorov Smirnov. Kelompok perlakuan A1B1 terdapat tingkat signifikan sebesar 0,676 berarti $\mathrm{p}>0,05$, artinya data berdistribusi normal. Pada kelompok perlakuan A1B2 terdapat tingkat signifikan sebesar 0,759 berarti $p>0,05$, artinya data berdistribusi normal. Pada kelompok perlakuan A2B1 terdapat tingkat signifikan sebesar 0,637 berarti $\mathrm{p}>0,05$, artinya data berdistribusi normal. Selanjutnya pada kelompok perlakuan A2B2 terdapat tingkat signifikan sebesar 0,655 berarti $\mathrm{p}>0,05$, artinya data berdistribusi normal. Berdasarkan analisis tersebut dapat disimpulkan bahwa data setiap kelompok terbukti berdistribusi normal, artinya distribusi data yang diobservasi tidak berbeda secara signifikan dari frekuensi yang diharapkan. Untuk selanjutnya statistik parametrik dapat digunakan.

\section{Uji Homogenitas Data}

Berdasarkan hasil analisis uji homogenitas dengan menggunakan uji Levene Test. Pada data pretest diperoleh nilai signifikansi sebesar $0,529>0,05$. Artinya dalam kelompok data memiliki varian yang homogen. Hasil perhitungan pada posttest di dapat nilai signifikansi sebesar 0,460 >0,05. Artinya kelompok data memiliki varian yang homogen. Sehingga data pada pretest dan posttest memiliki varian yang homogen. Selain itu memenuhi uji prasyarat sehingga uji statistik parametrik dapat dilanjutkan.

\section{Pengujian Hipotesis}

Pengujian hipotesis penelitian dilakukan berdasarkan hasil analisis data dan interpretasi analisis varian dua jalur. Analisis varian dua jalur untuk menguji pengaruh utama (main effect) antara variabel bebas metode latihan dan variabel atribut koordinasi (simple effect) terhadap keterampilan forehand drive petenis pemula. Uji Pairwise Comparisons untuk mrnguji rata-rata setelah analisis varian dua jalur guna mengetahui secara terperinci rata-rata yang beda. Berdasarkan hasil analisis varians dan Uji Pairwise Comparisons, ada beberapa hipotesis yang harus di uji.

Hipotesis I

Hipotesis yang dirumuskan adalah ada perbedaan pengaruh antara latihan imagery dengan menggunakan script imagery dan video imagery terhadap keterampilan forehand drive petenis pemula. Hasil perhitungan univariate test menunjukkan probabilitas (p) sebesar 0,25, karena $\mathrm{p}<0,05(0,025<0,05)$, sehingga hipotesis yang berbunyi ada perbedaan pengaruh antara latihan imagery dengan menggunakan script imagery dan video imagery terhadap keterampilan forehand drive petenis pemula diterima. Artinya ada perbedaan pengaruh antara latihan imagery dengan menggunakan script imagery dan video imagery terhadap keterampilan forehand drive petenis pemula. 


\section{Jurnal Keolahragaan 4 (2), September 2016 - 204}

Risti Nurfadhila

\section{Hipotesis II}

Hipotesis yang dirumuskan adalah ada perbedaan kemampuan keterampilan forehand drive antara petenis pemula yang memiliki koordinasi tinggi dan yang memiliki koordinasi rendah. Hasil perhitungan univariate test menunjukkan probabilitas (p) sebesar 0,030, karena $\mathrm{p}<0,05(0,030<0,05)$, sehingga hipotesis yang berbunyi ada perbedaan keterampilan forehand drive antara petenis pemula yang memiliki koordinasi tinggi dan yang memiliki koordinasi rendah, diterima. Artinya ada perbedaan kemampuan keterampilan forehand drive antara petenis pemula yang memiliki koordinasi tinggi dan yang memiliki koordinasi rendah.

Hipotesis III

Hipotesis yang dirumuskan adalah ada interaksi antara latihan imagery dan koordinasi terhadap keterampilan forehand drive petenis pemula. Hasil perhitungan Tests of BetweenSubjects Effeects menunjukkan probabilitas (p) sebesar 0,000, karena $\mathrm{p}<0,05(0,000<0,05)$, sehingga hipotesis yang berbunyi ada interaksi antara latihan imagery dan koordinasi terhadap keterampilan forehand drive petenis pemula, diterima. Artinya ada interaksi yang signifikan antara latihan imagery dan koordinasi terhadap keterampilan forehand drive petenis pemula.

Setelah diuji terdapat interaksi antara metode imagery dan koordinasi terhadap keterampilan forehand drive petenis pemula, maka untuk mengetahui kelompok sampel yang memberikan perbedaan signifikan dibandingkan dengan kelompok lain dilakukan uji lanjut dengan menggunakan Pairwise comparisons. Hasil uji lanjut Pairwise comparisons didapat kelompok yang berbeda secara signifikan, yaitu: (1) Pasangan antara script imagery dengan koordinasi tinggi dipasangkan dengan script imagery dengan koordinasi rendah (A1B1 dengan A1B2). (2) Pasangan antara script imagery dengan koordinasi rendah dipasangkan dengan video imagery dengan koordinasi tinggi (A1B2 dengan A2B1). (3) Pasangan script imagery dengan koordinasi rendah dipasangkan dengan video imagery dengan koordinasi rendah (A1B2 dengan A2B2).

Berdasarkan pengujian hipotesis menghasilkan dua kelompok kesimpulan analisis, yaitu: (1) Ada perbedaan pengaruh yang bermakna antara faktor-faktor utama penelitian. (2) Ada interaksi yang bermakna antara faktorfaktor utama dalam bentuk interaksi dua faktor.
Kelompok analisis tersebut dapat dipaparkan lebih lanjut sebagai berikut:

\section{Perbedaan Pengaruh antara Latihan Script Imagery dengan Video Imagery terhadap Keterampilan Forehand Drive}

Berdasarkan pengujian hipotesis ternyata ada perbedaan pengaruh yang nyata antara kelompok petenis pemula yang mendapatkan latihan script imagery dan video imagery. Pada kelompok petenis pemula yang dilatih dengan video imagery memiliki peningkatan keterampilan forehand drive lebih baik jika dibandingkan dengan petenis pemula yang diberikan script imagery.

Video imagery merupakan latihan imagery yang dilakukan dengan bantuan melihat video. Pada latihan video imagery termasuk multi-sensory karena dalam pelaksanaanya melibatkan banyak indera. Selain itu, dengan video imagery lebih mempermudah seseorang untuk menerka atau memahami suatu gerakan. Hal ini diperkuat pendapat Shearer $(2009$, p.9) menyatakan bahwa dengan video imagery membantu mengembangkan kemampuan imagery, memberikan gambaran yang detail/ rinci, multisensory, dan proposisi stimulus

Script imagery merupakan latihan imagery yang dilakukan dengan bantuan panduan naskah. Dalam pelaksanaanya script imagery membutuhkan daya konsentrasi dan intelegensi yang baik. Latihan imagery dapat membantu untuk meningkatkan daya imajinasi seseorang.

Smith \& Holmes (Shearer, 2009, p.3) menjelaskan video imagery lebih efektif daripada script imagery. Hal ini ditegaskan oleh Cho (2009, p.21) bahwa video imagery memiliki peningkatan performa yang lebih signifikan dibanding dengan script imagery. Hal ini dikarenakan video imagery memperlihatkan pengalaman performa secara nyata selama imagery. Jika dilihat dari kelebihan masing-masing latihan imagery di atas memang terlihat bahwa video imagery lebih unggul jika dibandingkan dengan script imagery. Hal ini karena video imagery bisa diterapkan pada semua petenis yang memiliki koordinasi tinggi atau rendah, sedangkan pada script imagery karena memerlukan konsentrasi, persepsi dan koordinasi tinggi. Bagi petenis yang memiliki koordinasi tinggi akan mudah melakukan sedangkan bagi petenis yang memiliki koordinasi rendah akan mengalami kesulitan.

Berdasarkan kajian tersebut, tampak bahwa latihan video imagery lebih baik daripada 
script imagery. Kebenaran teori tersebut diperkuat dengan hasil analisis data dalam penelitian ini yaitu: latihan video imagery memiliki peningkatan rata-rata sebesar 21,688, sedangkan latihan script imagery memiliki peningkatan rata-rata sebesar 18,063. Dari data tersebut disimpulkan bahwa latihan video imagery lebih baik jika dibandingkan dengan latihan video imagery terhadap keterampilan forehand drive petenis pemula.

Pelaksanaan treatment script imagery dan video imagery pada masing-masing kelompok dilakukan di ruangan yang berbeda, sehingga masing-masing kelompok tidak dapat melihat pelaksanaan treatment kelompok lain. Kelompok script imagery dalam memahami gerakan forehand drive hanya melalui naskah (script). Kelompok video imagery memahami gerakan forehand drive melalui video. Hal itu dimungkinkan kelompok video imagery lebih memahami gerakan forehand drive daripada kelompok script imagery, karena melihat gerakan forehand drive petenis profesional secara langsung sehingga mengetahui dengan jelas gerakan pada forehand drive. Hal ini menyebabkan adanya perbedaan pengaruh antar metode latihan terhadap keterampilan forehand drive

Perbedaan Pengaruh antara Koordinasi Tinggi dan Koordinasi Rendah terhadap Keterampilan Forehand Drive

Tenis lapangan merupakan olahraga yang memiliki gerakan kompleks. Salah satu gerakan yang kompleks adalah gerakan saat melakukan forehand drive. Untuk melakukan gerakan tersebut diperlukan koordinasi yang bagus agar dapat melakukan gerakan forehand drive secara benar. Sukadiyanto (2003, p.115) sebab tanpa memiliki kemampuan koordinasi gerak yang baik, individu akan kesulitan dalam belajar keterampilan teknik-teknik dasar pukulan tenis.

Berdasarkan pernyataan tersebut disimpulkan bahwa komponen koordinasi merupakan salah satu komponen biomotor yang harus dimiliki oleh petenis pemula. Dengan memiliki koordinasi yang baik maka petenis pemula dapat belajar gerakan-gerakan pada cabang olahraga tenis dengan mudah. Artinya petenis yang memiliki koordinasi tinggi akan lebih baik keterampilan forehand drivenya dibanding dengan petenis yang memiliki koordinasi rendah.

Hasil analisis data menunjukkan bahwa perbandingan rata-rata peningkatan keterampilan forehand drive, pada petenis pemula yang memiliki koordinasi tinggi lebih tinggi dibandingkan dengan atlet yang memiliki koordinasi rendah. Perolehan rata-rata keterampilan forehand drive sebesar 18,125 poin bagi petenis yang memiliki koordinasi tinggi. Hasil rata-rata keterampilan forehand drive sebesar 21,625 poin bagi petenis yang memiliki koordinasi rendah.

\section{Pengaruh Interaksi antara Latihan Script Imagery dan Video Imagery serta Koordinasi Tinggi dan Rendah terhadap Keterampilan Forehand Drive}

Hasil penelitian menunjukkan petenis pemula yang memiliki koordinasi tinggi akan memperoleh hasil yang lebih baik daripada petenis pemula yang memiliki koordinasi rendah jika dilatih dengan video imagery. Sebaliknya, petenis pemula yang memiliki koordinasi rendah akan memperoleh hasil yang lebih baik daripada petenis pemula yang memiliki koordinasi tinggi jika dilatih dengan script imagery. Hal tersebut berdasarkan teori dalam pelaksanaannya script imagery membutuhkan persepsi dan koordinasi yang tinggi sehingga akan lebih efektif apabila diterapkan pada petenis yang memiliki koordinasi tinggi. Pada petenis yang memiliki koordinasi rendah akan lebih efektif menggunakan video imagery, karena petenis akan lebih mudah memahami gerakan. Hal ini disebabkan video imagery melibatkan banyak pengindraan (multi-sensory) sehingga petenis mendapat gambaran yang jelas mengenai suatu gerakan.

Dari pernyataan tersebut disimpulkan bahwa keefektifan yang diterapkan untuk meningkatkan keterampilan forehand drive dipengaruhi oleh tinggi rendahnya kemampuan koordinasi yang dimiliki petenis pemula. Dengan demikian dalam menerapkan latihan harus disesuaikan dengan kemampuan dan karakter anak latih sehingga dapat mencapai hasil yang optimal.

\section{SIMPULAN}

Berdasarkan hasil penelitian disimpulkan sebagai berikut: (1) ada perbedaan pengaruh antara latihan imagery dengan menggunakan script dan video terhadap keterampilan forehand drive petenis pemula, (2) ada perbedaan keterampilan forehand drive antarkelompok koordinasi, dan (3) ada interaksi antara latihan imagery dan koordinasi terhadap keterampilan forehand drive. Interaksi tersebut sebagai berikut: (a) kelompok petenis pemula dengan 
kemampuan koordinasi tinggi yang dilatih dengan latihan script imagery memiliki pengaruh yang lebih baik daripada kelompok yang dilatih dengan latihan video imagery, dan (b) kelompok petenis pemula dengan kemampuan koordinasi rendah yang dilatih dengan video imagery memiliki pengaruh yang lebih baik daripada kelompok yang dilatih dengan latihan script imagery.

\section{DAFTAR PUSTAKA}

Brown, J. (2007). Step to success. (Terjemahan Dian Ruslaini). Jakarta: PT. Rajagrafindo Jaya.

Cho, S. K. (2009). Golfers' experience with multiple imagery interventions and putting performance. Tesis master, tidak diterbitkan, San Jose State University, California, United States.

Cholid, M. (2010). Petunjuk praktis bermain tenis. Malang: Club Tenis Gossypium Balittas Malang.

Dosil, J. (2006). The sport psychologist's handbook: A guide for sport-specific performance enhancement. Chichester: John Wiley \& Sons, Ltd.

Gunarso, S. D. (2008). Psikologi olahraga prestasi. Jakarta: Gunung Mulia.

Halim, N. I. (2009). Tes dan pengukuran kesegaran jasmani. Makasar: Badan Penerbit Universitas Negeri Makasar.

Huda, M. (2013). Model-model pengajaran dan pembelajaran. Yogyakarta: Pustaka Pelajar Offset.

Irianto, D. P., dkk. (2009). Materi pelatihan kondisi fisik dasar. Jakarta: Asdep Pengembangan Tenaga dan Pembina Keolahragaan.
Murphy, S. (2005). The sport psych handbook. Champaign, IL: Human Kinetics, Inc.

Purnama, K. S. (2013). Latihan imagery. Jurnal Iptek Olahraga, I (1), 34-47.

Rushall, B. S. (2008). Mental skills training for sports, (4th ed). Spring Valley: Sports Science Associates.

Shearer, D., et.al. (2009). The effects of a video-aided imagery intervention upon collective efficacy in an international paralympic wheelchair basketball team. Journal of Imagery Research in Sport and Physical Activity, 4, 1-25.

Sukadiyanto. (2010). Teori dan metodologi melatih fisik petenis. Yogyakarta: FIK UNY.

Sukadiyanto. (2005). Pengantar teori dan metodologi melatih fisik. Yogyakarta: Penerbit UNY.

Sukadiyanto. (2003). Keterampilan groundstroke petenis pemula. Disertasi doktor, tidak diterbitkan, PPS Universitas Negeri Jakarta, Jakarta.

Syafruddin. (2011). Ilmu kepelatihan olahraga. Padang: UNP Press.

Tenenbaum, G., \& Eklund, R. C. (2007). Handbook of sport psychology, $\left(3^{\text {rd }}\right.$ ed). New Jersey: John Wiley \& Sons, Inc.

Weinberg, R. S. \& Gould, D. (2007). Foundations of sport and exercise psychology. Champaign, IL: Human Kinetics.

Williams, S. E., et.al. (2013). Seeing the difference developing effective imagery scriptsfor athletes. Journal of Sport Psychology in Action, 4, 109-121. 